\title{
NK cell count as predictor of clinical response in patients with rheumatoid arthritis treated with rituximab
}

\section{Alfredomaria Lurati \\ Luca Bertani \\ Mariagrazia Marrazza \\ Katia Angela Re \\ Daniela Bompane \\ Magda Scarpellini}

Rheumatology Unit, Fornaroli Hospital, Magenta, Italy
Correspondence: Alfredomaria Lurati Rheumatology Unit, Fornaroli Hospital, 20013 Magenta, Italy

$\mathrm{Tel}+39297963836$

Fax +39297963903

Email alfredomaria.lurati@pec.it
This article was published in the following Dove Press journal:

Biologics: Targets and Therapy

10 April 2012

Number of times this article has been viewed

Purpose: The relationship between antiCD20 therapy with rituximab and the lymphocytes phenotype in patients with rheumatoid arthritis was investigated, with an attempt to establish a relationship between commonly used clinical activity indices and variations in leukocyte count, in particular natural killer (NK) lymphocytes.

Methods: Patients with seropositive (cyclic citrullinated peptides and rheumatoid factor positive) rheumatoid arthritis (according to the American College of Rheumatology 1987 criteria) refractory to conventional and antitumor necrosis factor-alpha agents who were subsequently treated with rituximab, a chimeric monoclonal antibody directed against CD20, were enrolled between January 2009 and September 2009. All subjects were treated with rituximab standard rheumatologic dose of $1.0 \mathrm{~g}$ on days 1 and 15 every 6 months for at least 2 years. A clinical evaluation was performed at baseline and subsequently every 3 months thereafter. At each assessment activated NK (CD56+/CD16+/CD54bright) cell count was collected and disease activity was assessed using Disease Activity Score in 28 Joints and the Simplified Disease Activity Index (SDAI).

Results: Thirty-four patients were enrolled (mean age \pm standard deviation: $54.8 \pm 12.8$ years). Basal SDAI was $21.75 \pm 5.4$ and NK cell count mean value was $157.6 \pm 90$. After 24 months, SDAI was $14 \pm 1.2$ and NK cell count mean value was $301.7 \pm 21(P<0.05)$. An inverted correlation between SDAI and NK count was observed at 3 months $(r=-0.36, P<0.05), 6$ months $(r=-0.48, P<0.45), 9$ months $(r=-0.47, P<0.05), 12$ months $(r=-0.41, P<0.01), 15$ months ( $r=-0.58, P<0.05), 18$ months $(r=-0.53, P<0.05), 21$ months $(r=-0.68, P<0.05)$, and 24 months $(r=-0.61, P<0.05)$. A linear regression model between all variables collected and SDAI/Disease Activity Score in 28 Joints at 6 months and 12 months confirmed a significant relationship between SDAI/Disease Activity Score in 28 Joints and NK cell count.

Conclusion: The data confirm the clinical efficacy of rituximab and suggests the use of NK cells as a predictor of clinical response in patients with rheumatoid arthritis.

Keywords: NK cells, rituximab, predictor, response, rheumatoid arthritis

\section{Introduction}

B cells have been implicated in the pathogenesis of rheumatoid arthritis (RA) since the discovery of circulating rheumatoid factor autoantibodies in RA patients. The successful introduction of $\mathrm{B}$ cell-depleting monoclonal antibodies as a treatment for patients with refractory RA confirmed the important role of B cells in RA. ${ }^{1}$ Rituximab is a chimeric monoclonal antibody directed against the $\mathrm{B}$ cell-specific membrane protein CD20, which is used in the treatment of B cell malignancies and was approved for use in the treatment of patients with RA. The exact mechanism of influence in the immune responses in autoimmune disorders leading to clinical remission is not yet known. 
B cell depletion and inhibition of antibody production are unlikely to explain all of its therapeutic effects. ${ }^{2-4}$ RA has a poorly understood pathogenesis, but the widely accepted view identifies rheumatoid factor as an epiphenomenon rather than an autoantibody directly implicated in disease. Furthermore, there is not a clear association between clinical improvement after rituximab therapy and B cell depletion, rheumatoid factor titer in RA, or lowering titers of anti-double-stranded DNA antibodies for lupus patients and, thus, research in rituximab therapy in autoimmune diseases includes seeking new biomarkers that may predict or measure therapeutic response. ${ }^{5,6}$

Natural killer (NK) cells are recognized by their cytotoxic and regulatory effects, implicated in prevention of autoimmunity. For example, NK cell frequency in peripheral blood is lower in patients with lupus when compared to healthy subjects and decreased values of NK cell counts are associated with higher levels of anti-double-stranded DNA. T CD4+/CD25high cells are important natural modulators of self-antigen $\mathrm{T}$ cell-mediated responses. While such natural regulatory $\mathrm{T}$ cells are reduced in patients with systemic lupus erythematosus, inducible CD4+/interleukin 10+ regulatory $\mathrm{T}$ cell count increases in systemic lupus erythematosus patients probably as result of a compensatory mechanism. ${ }^{7-12}$ To date, the literature is lacking a clear, clinically useful, early predictor of clinical response. ${ }^{13-17}$ In order to gain more insight into the clinical effects of B cell depletion in RA, the effects of antiCD20-mediated B cell depletion in the peripheral blood were investigated, with a focus on a possible relationship between NK activated cells (defined as CD56+/CD16+/ CD54 bright cells) and clinical response in terms of Disease Activity Score in 28 Joints (DAS28) and Simplified Disease Activity Index (SDAI). ${ }^{18}$

\section{Methods}

\section{Patients and study design}

All patients (enrolled between January 2009 and September 2009) were diagnosed according to the 1987 American College of Rheumatology (formerly, the American Rheumatism Association) criteria for $\mathrm{RA}^{19}$ and were positive for both rheumatoid factor and anti-cyclic citrullinated peptides (CCP). All patients had RA refractory to standard antitumor necrosis factor drugs, and so were treated with rituximab every 6 months at standard rheumatologic dose of two $1000 \mathrm{mg}$ intravenous infusions, separated by 2 weeks with $100 \mathrm{mg}$ intravenous methylprednisolone or equivalent before infusions, and accompanied by weekly $15 \mathrm{mg}$ subcutaneous methotrexate.

\section{Disease activity}

Disease activity was assessed using DAS28 and the composite index SDAI. SDAI is the numerical sum of five outcome parameters: tender and swollen joint counts (based on a 28-joint assessment), patient and physician global assessment of disease activity (visual analogue scale $0-100 \mathrm{~mm}$ ), and level of C-reactive protein (normal $<1 \mathrm{mg} / \mathrm{dL}$ ). The cut-off values for disease activity states are: remission $\leq 5$, low disease activity $\leq 20$, moderate disease activity $\leq 40$, and high disease activity $>40$. Calculations of DAS28 were based on the following: number of swollen and tender joints (employing the 28-joint count), evaluator's and/or patient's global assessment of disease activity, C-reactive protein, or erythrocyte sedimentation rate. The following formula is the basis for the calculation:

$$
\begin{aligned}
\text { DAS28 }= & \left(0.56 \times \mathrm{TJC}^{1 / 2}\right)+\left(0.28 \times \mathrm{SJC}^{1 / 2}\right) \\
& +(0.7 \times \ln [\mathrm{ESR}])+(0.014 \times \mathrm{GH})
\end{aligned}
$$

TJC and SJC represent tender and swollen joint count, respectively, ESR stands for erythrocyte sedimentation rate (mm/hour), and GH is patient's general health, ie, assessment of disease activity measured on a visual analog scale of $100 \mathrm{~mm}$.

\section{Flow cytometric analysis}

Fresh blood was collected by venipuncture in ethylenediaminetetraacetic acid-coated vials. Immunophenotyping was performed with the following monoclonal antibodies conjugated with fluorescein isothiocyanate, phycoerythrin, or phycoerythrin cyanine 5: CD54, CD16, CD56 (Immunotech, Marseille, France). The isotype-matched negative control used was mouse immunoglobulin G1 conjugated with fluorescein isothiocyanate, phycoerythrin, or cyanine (MOPC-21) monoclonal antibodies (BD Pharmingen, Milan, Italy). Fluorescence was measured using a FACScan ${ }^{\mathrm{TM}}$ flow cytometer (BD Biosciences, San Jose, CA). Briefly, $100 \mu \mathrm{L}$ of blood was labeled with $10 \mu \mathrm{L}$ monoclonal antibodies for 20 minutes in the dark. Red blood cells were removed by incubating the samples with lysing solution for 10 minutes in the dark. Tubes were centrifuged using a Hettich Zentrifugen EBA 21 (Tuttlingen, Germany) for 5 minutes at $1200 \mathrm{rpm}$. Samples were treated further with washing solution and were centrifuged for 5 minutes at $1200 \mathrm{rpm}$. Finally, cells were suspended in cell fixation solution and were ready for flow cytometry measurement. Lymphocytes were gated based on their forward and side-scatter characteristics. Information regarding the percentage of peripheral NK cells CD (CD56+/CD16+) expression was obtained. 
As reported by Bowles et $a 1,{ }^{20}$ quantification of the number of NK cells with bright expression of CD54 is a reproducible marker for NK activation induced by monoclonal antibodycoated tumor cells. The number of CD54bright NK cells was therefore evaluated as a measure of NK cell activation.

\section{Statistical analysis}

Pairwise comparisons were based on the Wilcoxon matchedpairs signed-rank test. Correlation between variables was evaluated with Spearman's rho.

All values of $P<0.05$ were considered to indicate statistical significance (two-tailed test). Linear regression models were estimated using all variables collected as covariates and SDAI and DAS28 as the dependent variable.

\section{Results}

Thirty-four patients were enrolled (mean age \pm standard deviation was $54.8 \pm 12.8$ years; 22 females, 12 males). Disease duration at the first course of rituximab was 5.8 years. Rheumatoid factor mean values were $115 \pm 25$ at baseline, $53 \pm 40$ after 1 year, and $47 \pm 20$ after 2 years $(P<0.05)$. CCP mean values were $86 \pm 30$ at baseline, $34 \pm 25$ after 1 year, and $39 \pm 30$ after 2 years $(P<0.05)$. DAS28 was $5.25 \pm 1.3$ at baseline, $4.47 \pm 0.7$ at 1 year, and $3.34 \pm 1.1$ after 2 years $(P<0.05)$. Basal SDAI was $31.75 \pm 5.4$ and NK cell count mean value was $157.6 \pm 90$. After 1 year SDAI was $18.3 \pm 20.2$ and NK cell count was $221 \pm 90(P<0.05)$. After 24 months SDAI was $14 \pm 1.2$ and NK cell count was $301.7 \pm 21(P<0.05)$. SDAI, DAS28, and NK cell count were assessed every 3 months. An inverse correlation between SDAI and NK cell count was observed at 3 months $(r=-0.36, P<0.05), 6$ months $(r=-0.48, P<0.05)$, 9 months $(r=-0.47, P<0.05), 12$ months $(r=-0.41$, $P<0.01), 15$ months $(r=-0.58, P<0.05), 18$ months ( $r=-0.53, P<0.05), 21$ months $(r=-0.68, P<0.05)$, and 24 months $(r=-0.61, P<0.05)$ (Figures 1 and 2$)$. Also, DAS28 values were related to NK cell count at 3 months $(r=-0.25$, $P<0.05), 6$ months $(r=-0.38, P<0.05), 9$ months $(r=-0.37$, $P<0.05), 12$ months $(r=-0.51, P<0.01), 15$ months ( $r=-0.59, P<0.05), 18$ months $(r=-0.57, P<0.05)$, 21 months $(r=-0.61, P<0.05)$, and 24 months $(r=-0.58$, $P<0.05)$. Subsequently, a linear regression least squares model backward method showed a significant correlation index between NK cell count modification at 3 months and SDAI/ DAS28 response at 6 months and 12 months $\left(R^{2}=0.73 / 0.71\right.$ and $0.70 / 0.71$, respectively; $P<0.05$ ), independent from other variables collected (CCP, rheumatoid factor, $C$-reactive protein, and erythrocyte sedimentation rate values, age, and disease duration) (Figures 1 and 2).

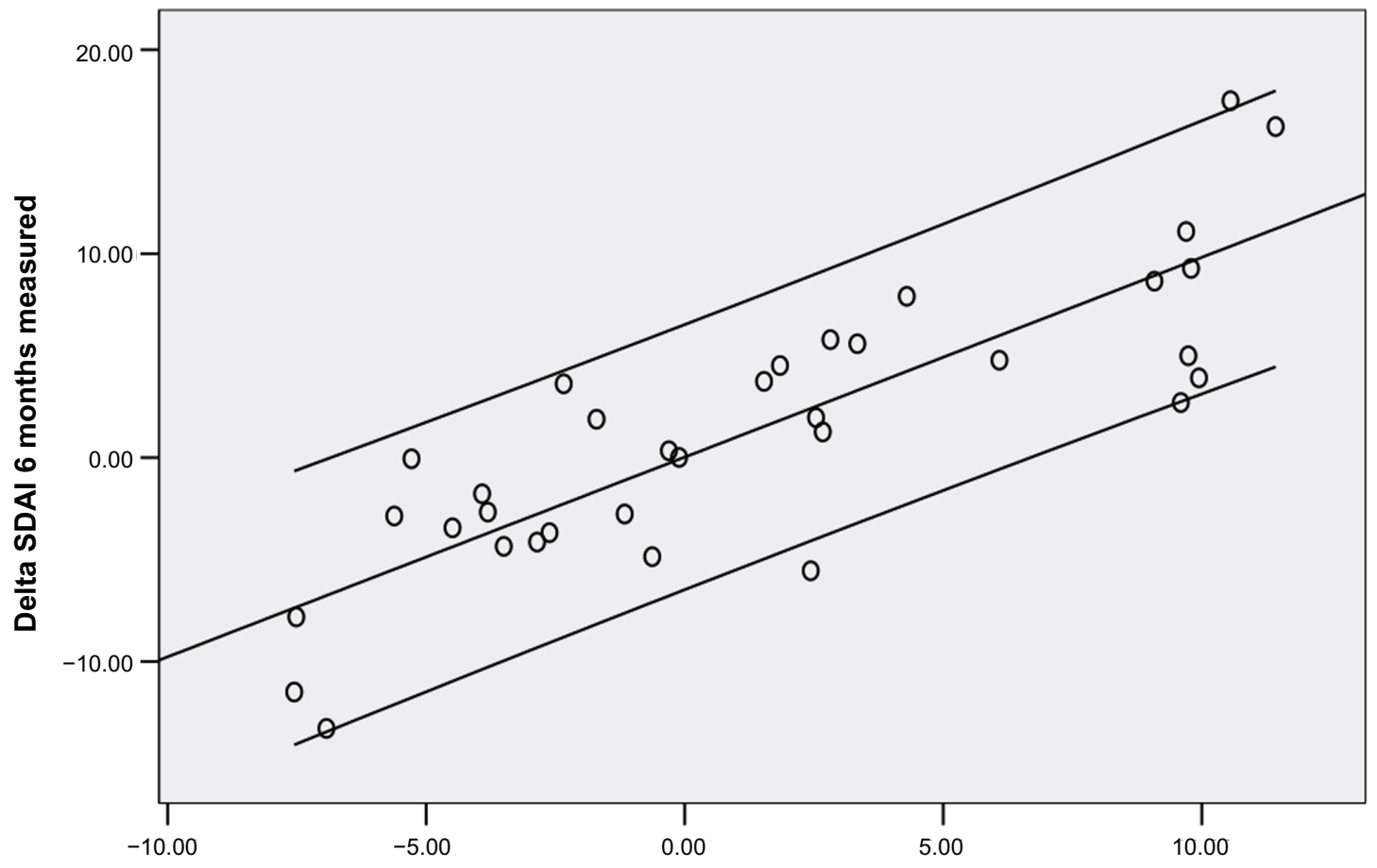

Regression adjusted predicted value delta SDAI 6 months

Figure I Relationship between Simplified Disease Activity Index values measured ( $Y$ axis) and predicted $(X$ axis) at 6 months with a linear regression model based on natural killer cell count at 3 months.

Abbreviation: SDAI, Simplified Disease Activity Index. 


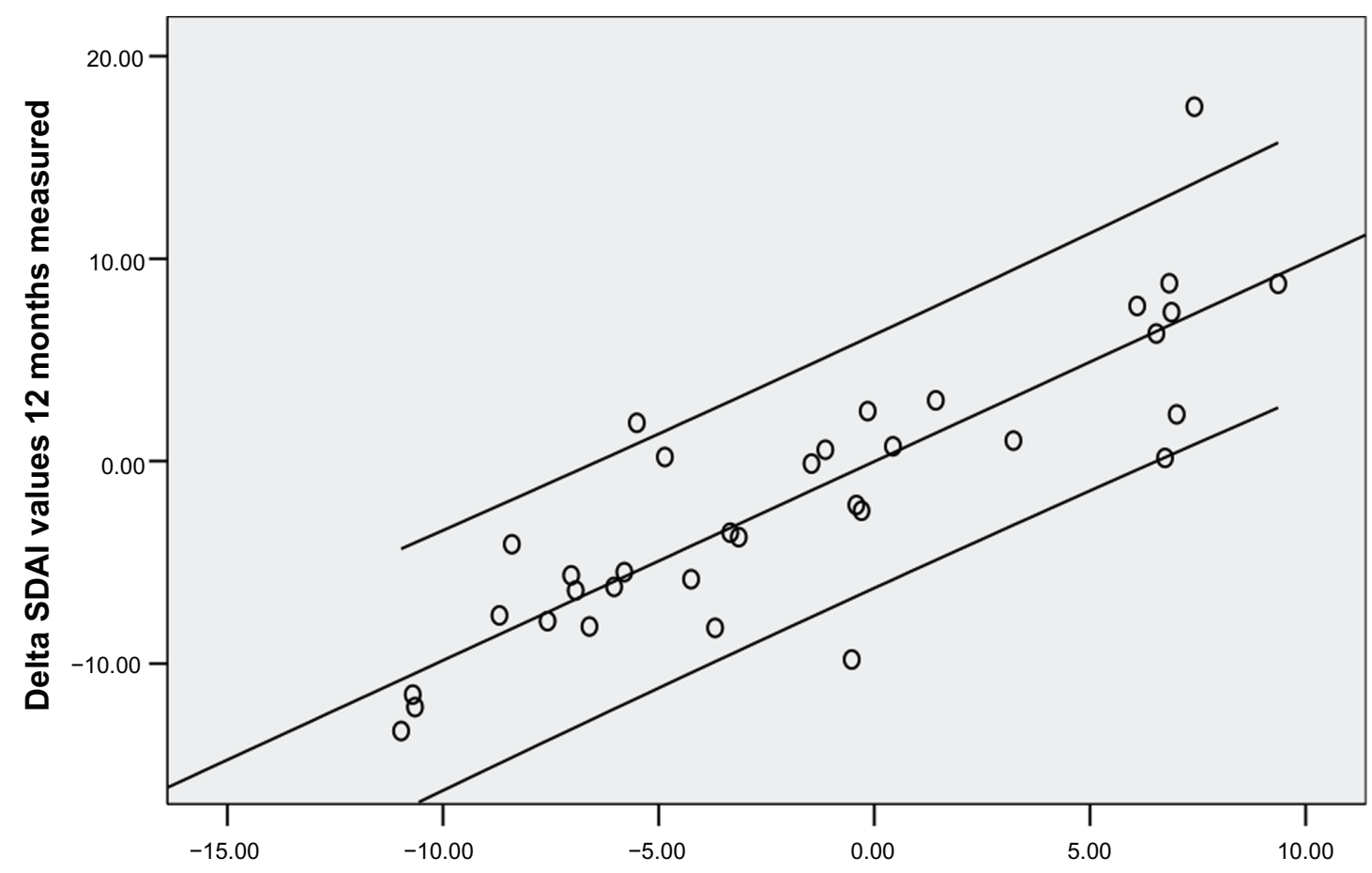

Regression adjusted predicted value delta SDAI 12 months

Figure 2 Relationship between Simplified Disease Activity Index values measured ( $\mathrm{Y}$ axis) and predicted ( $\mathrm{X}$ axis) at $\mathrm{I} 2$ months with a linear regression model based on natural killer cell count at 3 months.

Abbreviation: SDAI, Simplified Disease Activity Index.

\section{Discussion}

The role of B cells in immunopathogenesis of RA has not been fully characterized, but several possible mechanisms of action have been proposed: B cells may function as an antigen presenting cells with costimulatory signals required for $\mathrm{T}$ cell $\mathrm{CD} 4$ regulation, they may also secrete proinflammatory cytokines (eg, tumor necrosis factor, interleukin 6, and other chemokines), and may regulate immune response during RA contributing to inflammation and bone erosions..$^{21,22}$ There is also recent evidence regarding the involvement of NK cells in RA. NK cells originate from $\mathrm{CD} 34+$ hematopoietic progenitor cells and have been defined by flow cytometry as CD56+/CD16+ typical adult or mature cells, CD56+/CD16 immunoregulatory cells, and CD56-/CD16+ cytotoxic cells. ${ }^{23-25}$ NK cells have been detected in the synovium and elevated concentrations have been recorded in peripheral blood. NK cells may contribute to the pathogenesis of RA by perforin- or granzyme-mediated cytotoxicity and cytokine production. ${ }^{26-30}$ CD20-specific antibody rituximab has been proven to be a successful treatment for B cell malignancies and recently for RA. The binding of rituximab to CD20+ B cells results in $\mathrm{B}$ cell depletion through three mechanisms of action: antibody dependent complement mediated cytotoxicity, antibody-dependent cell-mediated cytotoxicity, and CD20+ $\mathrm{B}$ cell apoptosis. The depletion of peripheral B cells occurs immediately following the two infusions of rituximab, but different levels of clinical response have been achieved and therefore it is not possible to predict response on the basis of initial peripheral B cell depletion. NK cells appear to play a central role in mediating the effects of monoclonal antibody therapy including rituximab as effector cells of antibody-dependent cell-mediated cytotoxicity. ${ }^{20,31,32}$ In a preliminary study in 2009, a probable reverse relationship between DAS28 response and NK cell count in patients treated with a single course of rituximab was suggested. ${ }^{33}$

In the present long-term study, the relationship between NK cell activation (defined as an upregulation of CD54) mediated by rituximab and clinical response in patients with active RA was evaluated. Also, the use of NK cell count was tested as a predictor of clinical response. The chief finding was that the activation of NK cells 3 months after the first rituximab course was significantly related to clinical response at 6 months and 1 year, independent from other clinical variables such as C-reactive protein or CCP values, suggesting that NK activated cells can be used as an early predictor of clinical response. 


\section{Disclosure}

The authors report no conflicts of interest in this work.

\section{References}

1. Cohen SB, Emery P, Greenwald MW, et al; REFLEX Trial Group. Rituximab for rheumatoid arthritis refractory to anti-tumor necrosis factor therapy: results of a multicenter, randomized, double-blind, placebo controlled, phase III trial evaluating primary efficacy and safety at twenty-four weeks. Arthritis Rheum. 2006;54(9):2793-2806.

2. Stohl W, Looney RJ. B cell depletion therapy in systemic rheumatic diseases: different strokes for different folks? Clin Immunol. 2006;121(1):1-12.

3. Strand V, Kimberly R, Isaacs JD. Biologic therapies in rheumatology: lessons learned, future directions. Nat Rev Drug Discov. 2007;6(1):75-92.

4. Sfikakis PP, Boletis JN, Lionaki S, et al. Remission of proliferative lupus nephritis following B cell depletion therapy is preceded by down-regulation of the $\mathrm{T}$ cell costimulatory molecule CD40 ligand: an open-label trial. Arthritis Rheum. 2005;52(2):501-513.

5. Tanaka Y, Yamamoto K, Takeuchi T, et al. A multicenter phase I/II trial of rituximab for refractory systemic lupus erythematosus. Mod Rheumatol. 2007;17(3):191-197.

6. Kavanaugh A, Rosengren S, Lee SJ, et al. Assessment of rituximab's immunomodulatory synovial effects (ARISE trial). 1: clinical and synovial biomarker results. Ann Rheum Dis. 2008;67(3):402-428.

7. Shi FD, Van Kaer L. Reciprocal regulation between natural killer cells and autoreactive T cells. Nat Rev Immunol. 2006;6(10):751-760.

8. Miyake S, Yamamura T. NKT cells and autoimmune diseases: unraveling the complexity. Curr Top Microbiol Immunol. 2007;314:251-267.

9. Green MR, Kennell AS, Larche MJ, Seifert MH, Isenberg DA, Salaman MR. Natural killer cell activity in families of patients with systemic lupus erythematosus: demonstration of a killing defect in patients. Clin Exp Immunol. 2005;141(1):165-173.

10. Green MR, Kennell AS, Larche MJ, Seifert MH, Isenberg DA, Salaman MR. Natural killer T cells in families of patients with systemic lupus erythematosus: their possible role in regulation of IGG production. Arthritis Rheum. 2007;56(1):303-310.

11. Shevach EM, Piccirillo CA, Thornton AM, McHugh RS. Control of $\mathrm{T}$ cell activation by CD4+CD25+ suppressor T cells. Novartis Found Symp. 2003;252:24-44, 106-114.

12. Barath S, Aleksza M, Tarr T, Sipka S, Szegedi G, Kiss E. Measurement of natural (CD4+CD25high) and inducible (CD4+IL-10+) regulatory $\mathrm{T}$ cells in patients with systemic lupus erythematosus. Lupus. 2007;16(7):489-496.

13. Breedveld F, Agarwal S, Yin M, et al. Rituximab pharmacokinetics in patients with rheumatoid arthritis: B-cell levels do not correlate with clinical response. J Clin Pharmacol. 2007;47(9):1119-1128.

14. Dass S, Rawstron AC, Vital EM, Henshaw K, McGonagle D, Emery P. Highly sensitive B cell analysis predicts response to rituximab therapy in rheumatoid arthritis. Arthritis Rheum. 2008;58(10): 2993-2999.

15. Dass S, Burgoyne CH, Vital EM, et al. Reduction in synovial B cells after rituximab in RA predicts clinical response [abstract]. Ann Rheum Dis. 2007;66 Suppl 2:ii90.

Biologics: Targets \& Therapy

\section{Publish your work in this journal}

Biologics: Targets \& Therapy is an international, peer-reviewed journal focusing on the patho-physiological rationale for and clinical application of Biologic agents in the management of autoimmune diseases, cancers or other pathologies where a molecular target can be identified. This journal is indexed on PubMed Central, CAS, EMBase, Scopus
16. Teng YK, Levarht EW, Hashemi M, et al. Immunohistochemical analysis as a means to predict responsiveness to rituximab treatment. Arthritis Rheum. 2007;56(12):3909-3918.

17. Thurlings RM, Vos K, Wijbrandts CA, Zwinderman AH, Gerlag DM, Tak PP. Synovial tissue response to rituximab: mechanism of action and identification of biomarkers of response. Ann Rheum Dis. 2008;67(7):917-925.

18. Smolen JS, Breedveld FC, Schiff MH, et al. A simplified disease activity index for rheumatoid arthritis for use in clinical practice. Rheumatology (Oxford). 2003;42(2):244-257.

19. Arnett FC, Edworthy SM, Bloch DA, et al. The American Rheumatism Association 1987 revised criteria for the classification of rheumatoid arthritis. Arthritis Rheum. 1988;31(3):315-324.

20. Bowles JA, Wang SY, Link BK, et al. Anti-CD20 monoclonal antibody with enhanced affinity for CD16 activates NK cells at lower concentrations and more effectively than rituximab. Blood. 2006;108(8):2648-2654.

21. Martinez-Gamboa L, Brezinschek HP, Burmester GR, Dorner T. Immunopathologic role of B lymphocytes in rheumatoid arthritis: rationale of B cell-directed therapy. Autoimmun Rev. 2006;5(7):437-442.

22. Edwards JC, Szczepanski L, Szechinski J, et al. Efficacy of B-celltargeted therapy with rituximab in patients with rheumatoid arthritis. N Engl J Med. 2004;350(25):2572-2581.

23. Coppieters K, Dewint P, Van Beneden K, et al. NKT cells: manipulable managers of joint inflammation. Rheumatology (Oxford). 2007;46(4): $565-571$.

24. Groh V, Bruhl A, El-Gabalawy H, Nelson JL, Spies T. Stimulation of $\mathrm{T}$ cell autoreactivity by anomalous expression of NKG2D and its MIC ligands in rheumatoid arthritis. Proc Natl Acad Sci U S A. 2003;100(16):9452-9457.

25. Namekawa T, Snyder MR, Yen JH, et al. Killer cell activating receptors function as costimulatory molecules on CD4+CD28null $\mathrm{T}$ cells clonally expanded in rheumatoid arthritis. $J$ Immunol. 2000;165(2):1138-1145.

26. Warrington KJ, Takemura S, Goronzy JJ, Weyand CM. CD4+,CD28- T cells in rheumatoid arthritis patients combine features of the innate and adaptive immune systems. Arthritis Rheum. 2001;44(1):13-20.

27. Cooper MA, Fehniger TA, Fuchs A, Colonna M, Caligiuri MA. NK cell and DC interactions. Trends Immunol. 2004;25(1):47-52.

28. Cooper MA, Fehniger TA, Caligiuri MA. The biology of human natural killer-cell subsets. Trends Immunol. 2001;22(11):633-640.

29. Mendes R, Bromelow KW, Westby M, et al. Flow cytometric visualization of cytokine production by CD3-CD56+ NK cells and CD3+CD56+ NK-T cells in whole blood. Cytometry. 2000;39(1):72-78.

30. Reis EA, Athanazio DA, Lima I, et al. NK and NKT cell dynamics after rituximab therapy for systemic lupus erythematosus and rheumatoid arthritis. Rheumatol Int. 2009;29(4):469-475.

31. Leandro MJ, Cambridge G, Ehrenstein MR, Edwards JC. Reconstitution of peripheral blood B cells after depletion with rituximab in patients with rheumatoid arthritis. Arthritis Rheum. 2006;54(2):613-620.

32. Assous N, Gossec L, Dieudé P, et al. Rituximab therapy in rheumatoid arthritis in daily practice. $J$ Rheumatol. 2008;35(1):31-34.

33. Lurati A, Marrazza MG, Re KA, Scarpellini M. Relationship between NK cell activation and clinical response in rheumatoid arthritis treated with rituximab. Int J Biomed Sci. 2009;5(2):92-95.

\section{Dovepress}

and the Elsevier Bibliographic databases. The manuscript management system is completely online and includes a very quick and fair peerreview system, which is all easy to use. Visit http://www.dovepress. $\mathrm{com} /$ testimonials.php to read real quotes from published authors. 